From teachers into multiply skilled persons: How was art education implemented at a Finnish teacher training college in 1921-1970?

Paksuniemi, Merja

Institute of Migration, Finland (Merja.Paksuniemi@ rovaniemi.fi)

Uusiautti, Satu $\bigotimes$

Faculty of Education, University of Lapland, Finland (satu@ uusiautti.fi)

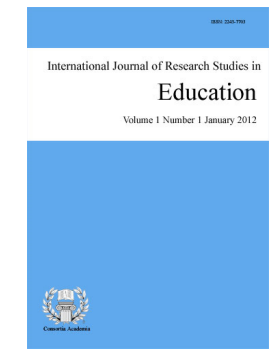

ISSN: 2243-7703 Online ISSN: 2243-7711

OPEN ACCESS

Määttä, Kaarina

Faculty of Education, University of Lapland, Finland (kaarina.maatta@ulapland.fi)

\title{
Abstract
}

The purpose of the article is to describe education provided at the Teacher Training College of Tornio located in Northern Finland in 1921-1970. Teacher training was based on the educational trend of Herbart-Zillerism and the aim of education was to develop strong moral-religious character. In this study, the research approach was educational historical and the data were comprised of archival sources, annuals, and contemporary textbooks complemented by interview data in which nine former teacher students of the college reminisced their experiences. Art education at the teacher training colleges covered playing and singing, manual skills, and gymnastics, games, and sports. The results showed how teachers were expected to be able to accompany hymns, spiritual and patriotic songs, to solo sing, and to master a choir. Teachers had to be sportive and able to patch up and sew clothes to themselves and their families. In addition, teachers were expected to be diligent, even-tempered, brisk, careful, and handy. Teachers acted as role models for their pupils and set an example of model citizens. The role of art education both in teacher education and in school is speaking to people still today. Knowledge of the past makes a useful adjunct to the discourse.

Keywords: teacher education; art education; handicraft education; Herbart-Zillerism; history of education 


\section{From teachers into multiply skilled persons: How was art education implemented at a Finnish teacher training college in 1921-1970?}

\section{Introduction}

The Finnish School System was changed comprehensively at the beginning of the 1920s when the Act on Compulsory Education in 1921 obliged municipalities to arrange education for all children aged 7-12. It meant that new schools were established both in country sides and cities and the lack of teachers was substantive (Iisalo, 1989; Kuikka, 1991; Melin, 1980; Nurmi, 1989). At the beginning of the 20th century, new teacher training colleges were established and the northernmost one was situated in Tornio (Paksuniemi, 2009).

Teacher training provided at Finnish colleges was somewhat uniform. Textbooks, learning requirements and skills and knowledge required of students were mostly similar (Halila, 1963; Heikkinen, 1990; Hyyrö, 2006; Isosaari, 1961; Nurmi, 1995; Paksuniemi, 2009; Rinne, 1989). The German educational trend of Herbart-Zillerism was prevailing at the Finnish teacher training colleges (Halila, 1949; Heikkinen, 1995; Nurmi, 1964). According to it, the purpose of education and teaching was to develop a moral character with the emphasis on decency-Christianity, patriotism (e.g. Halila, 1963; Isosaari, 1961; Melin, 1980), and teacher-led teaching in the classroom situations. Hobbyism was a significant part of teaching and the teacher personality. A teacher acted as a role model for his or her pupils and therefore, the teacher had to not only master teaching but also know how to dress and behave as an educated person (Paksuniemi, 2009; Paksuniemi \& Määttä, 2011a; Paksuniemi \& Määttä, 2011b). Indeed, art education ${ }^{1}$ was focused on promoting teachers' hobbyism.

How the importance of art education was seen in schooling and teacher education is mainly based on art conceptions that have sought their positions in art education for decades. Therefore, the versatile and contradictory nature of art education is not any new perception. Already at the beginning of the 20th century, Juho Hollo (1919) wrote about the conceptual ambiguity and heterogeneity of the idea of art education. The following notion made by Hollo gives an insight how to understand the nature of art education and the spirit of teacher training over 80 years ago - and it might well describe today's situation as well:

Naturally, it is greatly up to the individual and thus causing enthusiastic disagreement about which and what kind of art each of us wants to favor as the means or goal of education: someone may only resort to so-called classic art while some other may demonstrate obvious apt for noticing the latest trends. This is closely connected with the above-mentioned ambiguity of the purpose of art education: as the opinions on the purpose of art change and are disputed-for some art is just a servant of religion or moral, for some it is a social factors, and for others it is just art for art itself, and many others - art education has the most various tasks depending on the viewpoint (Hollo, 1919, pp. 145-146).

Because of the obscurity of the definition, Hollo (1919) wanted to give up the word "art education" and instead use the concept of "aesthetic education". He defined aesthetic education as "cultivating various points of the imaginary in a balanced manner" (Hollo, 1919, p. 152). It meant the development of emotional life toward strength and rich in nuances, and imagination into fast—and the balance between these two. According to Hollo, it can be fostered in many subjects, including art education.

\footnotetext{
${ }^{1}$ In this article, we use the word 'art education' to cover the following nine different art forms: music, literary arts, dance, performing arts (circus and theatre) and visual arts (architecture, audiovisual art, visual arts, and craft). Today, the objectives and core contents are determined in national core curricula devised by the Finnish National Board of Education (see http://www.oph.fi/english/education/basic_education_in_the_arts)
} 


\section{Materials and methods}

In this research, the educational-historical research approach (Aldrich, 2003; McGulloch \& Watts, 2003) was employed to dissect how the teaching of art education took place at the teacher training colleges, especially at the teacher training college of Tornio, in Northern Finland. It was a women's college and operated in 1921-1970.

The sources used in the research are mostly primary sources: archival sources, annuals, and contemporary textbooks. The archival sources were the classroom diaries of the college, the exchange of letters of the seminar, and curricula. They cover the whole operational period of the college. The archival sources were analyzed at the Provincial Archives of Oulu. The textbooks that are referred to in this paper were actually used at the college. The textbooks were analyzed and a holistic picture of their contents was drawn in order to answer the research questions. The textbooks were acquired from the textbook depository located in Helsinki, Finland. The secondary sources of the research comprise the research literature about the Finnish teacher training colleges and the importance of music, handicraft, and sport in the Finnish society in general.

In addition, nine former teacher students at the teacher training college of Tornio were interviewed. They all were women aged between 60 and 85 years and they were asked to reminisce, describe, and interpret their studying at the college (see Granfelt, 1998; Scott, 1991; Ukkonen, 2002). The interviewees studied at the college in different decades and they were found with the help of the archival materials. Of the participants, Kerttu studied in the end of the 1930s, Armi and Raija in the 1940s, Marjatta and Elli in the beginning of the 1950s, Ritva and Leena at the beginning of the 1960s, Anni in the middle of the 1960s, and Pirjo in the end of the 1960s. The former teacher students were interviewed individually at their own homes during the years 2009-2011. An abundant, even life-historical data were gathered and it comprised approximately 200 pages as a transcript (see Merseth, 1991; Woods, 1985).

The following research questions were set at this study:

1. What were the emphases of art education?

2. How did the teacher students perceive the teaching and studying of art education?

\section{Results}

\subsection{Harmonium playing and choir singing}

Teacher students who could not play when starting at the college began with the basics. First-year students practiced the basics of playing, such as the correct sitting position and reading of notes. Along the study years, students got to practice more demanding songs and dozens of chorales (hymn accompaniments) (Annuals 1921-1970; see also Hymander \& Ahlfors, 1906; Paavola, 1949; Wohlfahrtin \& Merikanto, 1904). Marjatta remembered: "I was glad that I could play a little! It made studying easier".

The extensive practicing of chorales was usual at Finnish teacher training colleges. At the college of Jyväskylä for example, teacher students had to learn dozens of chorales (Halila, 1963; Hyyrö, 2006). In addition, students were advised how to take care of and handle a harmonium (OMA, TSeA, Dd:1; OMA, TSeA, Dd:2; Annuals1930-1970). Harmonium maintenance was an important skill. The instrument was expensive and careful, regular maintenance guaranteed several years of playing. A school could be located in a remote place where it was not necessarily easy to get a maintenance man to visit.

The purpose of practicing playing was to achieve a certain level to be able to accompany songs and hymns in the teaching. The idea of the father of Finnish elementary school, Uno Cygnaeus, was that those students who could already play when starting studies at the college would advance to the level that they would be able to play 
at services (Cygnaeus, 1910). Learning to play was challenging to some students because starting from the 1930s, student candidates did not have to know how to play already beforehand as was required still in the 1920s' entrance tests (Contemporary Regulation 25 May 1918; OMA, TSeA, Ca:2; OMA, TSeA, Ca:3; OMA, TSeA, Ca:4; OMA, TSeA, Ca:5; OMA, TSeA, Ca:6; OMA, TSeA, Ca:7; OMA, TSeA, Ca:8). Anni stated: "I had to work a lot with music because I wasn't musical. I spent so much time in that music room as we had to learn dozens of hymns. Afterwards, I have said that I could have become anything if I had been allowed to use the time for something else". Ritva had found playing laborious as well: "And I did say that I will never touch a harmonium or a piano when I leave".

College students practiced playing with harmoniums daily, half an hour at a time, and had demonstration playing 15-20 minutes per week. The latter meant that a teacher student would play homework songs to the music teacher and was then given new songs to practice (OMA, TSeA, Dd:1; OMA, TSeA, Dd:2; Annuals 1921-1970). This was how students' achievements were controlled. Teacher students practiced in particular playing booths. Maija remembered: "You had to book playing time". According to the students, the music teacher came to check every now and then whether the student was practicing at his or her own turn. The action was a sort of optional necessity, as several interviewees remembered. The demonstration playing was given once a week (Annuals 1939-1945).

Teacher students had to accompany hymns sang at college morning devotions in turns. It was a challenging task but an aspired one, too, because it showed that one was able to take a real working life challenge and for some, it could mean even a rise of the music grade. On the other hand, it motivated students to play hymns. The music teacher let a student know when his or her skills were sufficient. Those who were skillful could also perform at the college parties, noted at least Anni, Armi, Kerttu, Leena, and Ritva. Accompaniment of hymns was good practice for the future teacher's career. Kerttu stated the following: "You had to keep your end up in that accompaniment of morning hymn". It was not obligatory but the most advanced students could play. Pirjo reminisced: "Those who could play well, they accompanied. I didn't accompany, I didn't want to".

In the 1900s, Cygnaeus wrote that the teaching of singing at teacher training colleges had the following goals: The teaching of singing, that has to be regarded as a salient educational power and must therefore be practiced, means the arousal and development of a student's religious, decent, and aesthetic feeling, the exaltation of singing at church, school, home, and social life, by doing chants and practicing patriotic folk songs. Furthermore, a college student has to learn to teach singing at elementary school (Cygnaeus, 1910). The objectives were reflected in the elementary teacher training curricula of the college of Tornio as well. Students sang children's songs and play-songs, hymns, and spiritual and patriotic songs. In singing lessons, they also studied rhythmic, and the theory and history of music (OMA, TSeA, Ae.2; OMA, TSeA, Ae:19; OMA, TSeA, 21; OMA, TSeA, 28; Annuals 1921-1970; see also Helasvuo, 1961; Ingman, 1962; Kotilainen, 1924; Lahtinen \& Lampén, 1927; Lahtinen \& Lampén, 1931; Parviainen, 1936; Parviainen, 1946; Siukonen, 1954; Törnudd, 1920; Törnudd, 1923; Vainio, 1920). Ritva reminisced: “Those music lessons were extremely good ones. And the theory of music was really efficient".

Teacher students of the college of Tornio practiced choir singing during singing lessons and also after school days. The college choir did perform quite often not only in occasions at the college but also in parties in the town. The college choir also co-operated with the parish of Tornio by performing in parish events (OMA, TSeA, Ca:1; OMA, TSeA, Ca:2; Annuals 1922-1970). This was brought up in the interviews, too. Leena said: "The choir went often to sing at church, we performed there. So we worked very closely with the parish". The college choir had concerts and the profits from the sale of tickets were used in general choir activities (Annuals 1921-1970). The choir members were wearing national dresses when performing. Tours were moments when the students who otherwise were strictly inside the college building could get in touch with the outside world: "We practiced once a week and went to perform elsewhere, too. Those were fun moments." (Ritva). The college education aimed at graduation and becoming prepared for the teacher's work. The purpose of choir activity was to teach prospective teachers choir singing and how to act as a choirmaster. Choir activity was quite a common hobby at 
Finnish colleges (e.g. Halila, 1963; Heikkinen, 1995; Hyyrö, 2006; Hyry \& Hyvönen, 2003).

\subsection{Practical manual skills}

Teacher students practiced pottering, water coloring, charcoal drawing, and practical manual skills, such as how to stitch and do paper and cardboard pieces and embroidery. In addition, they learned how to sew with bast fibre and fishnets. During lessons, teacher students made booties, handicraft pouches, and beanbags and other crafts that elementary school handicraft courses included. The purpose was to learn the basic working skills and how to prepare ready teaching material. They also practiced doing other practical handicrafts needed in everyday life: they prepared, for example, gym clothes, a doll with doll clothing, mittens and socks, a child's vest, a girl's blouse, a bolster scarf, a national dress or a summer dress, a woman's shirt, a purse, and a knit. In addition, they learned how to crochet wool, sew up, patch, repair, and maintain. Clothes and handicrafts that teacher students made varied a little during decades (OMA, TSeA, Ae:2; OMA, TSeA, Ae:19; OMA, TSeA, 21; OMA, TSeA, 28; Annuals, 1921-1970). Many of the interviewees told how national dresses were made still in the 1940s but no longer at the end of the 1960s. Making national dresses illustrates the importance of national heritage, patriotism and regionalism in education. Sewing a national dress was a long and demanding process for which several lessons were reserved per study year (e.g. OMA, TSeA, Ae:2).

Textbooks advised prospective teachers of what to produce during handicraft lessons, how to instruct pupils, and how lessons should proceed. Textbooks also taught various handicraft skills needed in everyday life in general (e.g. Teerisuo, 1950; Teerisuo, 1964; Turunen, 1946; Turunen, 1966; Törnudd, 1929; Valve \& Tappura, 1937). Raija told: "In the very first handicraft lesson, we learned to sew tabs in towels. That was a good and useful basic skill”. Textbooks also included a definition of a good teacher's qualities. In Törnudd's (1929) book, they were a staid being and fairness. Joking and small talk were not regarded as a part of a teacher's job description but a teacher had to be serious and diligent. However, even this was not enough but a teacher had to pay attention to his or her speech, clothing, and appearance. Although pieces that were made in handicraft lessons resembled children's world, working must not be hasty or playful (Törnudd, 1929).

One of the themes was to educate students into austerity. Prospective elementary school teachers had to be able to patch and sew up clothes. The point was to raise economic citizens. The depression partly made the theme topical in handicraft lessons. The scarcity of materials inspired students to make pieces from "waste". In practice, it meant that materials were recycled and for example post cards, matchboxes, and bobbins were reused for this purpose (OMA, TSeA, Dd:1; OMA, TSeA, Dd:2; OMA, TSeA, Ae:19; Annuals, 1930-1939). According to Tuomaala (2004), knowing how to cut paper was an important pre-phase of drawing tracing papers. The drawing of tracing papers was important so that students would be able to make clothes both for themselves and their families (Tuomaala, 2004). As students did not have time to finish their handicrafts during the lessons, they continued making them during their leisure: "Usually, we spent evenings in the students' hall of residence doing handicrafts. We had to do a lot of them." (Pirjo). According to Seija, handicrafts took plenty of time: "We just did those handicrafts; we had to do them during our free-time. So, we did them all nights long”.

Cygnaeus's thoughts affected education as handicrafts were considered a part of national civilization and everyday life (Cygnaeus, 1910; see Somerkivi, 1985). Indeed, the goal of teaching seemed to have been not only to learn new skills but also to make useful pieces. These skills were important in a teacher's work and for a woman's role in the society overall (see Heikkilä, 2008). Prospective teachers were guided toward husbandry: sewing up and patching clothes were economical skills - naturally, they were mothers' tasks as well.

\subsection{Sport and folklore}

Compared with other subjects, teacher students had PE lessons the most. During the first study year and the fall semester of the second year, they had it five hours a week and six hours a week during the spring semester of the second study year. The themes covered gymnastics, skiing, various games and plays, folk dances, and singing 
games (OMA, TSeA, Dd:1;OMA, TSeA, Dd:2; Annuals 1921-1970). Armi reminisced: "We studied folk dances conscientiously. Then it was time to learn polka. I remember how we were jumping polka steps to playing rehearsal". Ritva remembered: "We were all taught how to dance. In the PE lessons, we learned all Finnish dances". In addition, they were taught how to teach fairy gym and gymnastic at desks. The latter refers to a specially designed gymnastic for elementary schools without a separate gym class facilities, especially rural elementary school. Following Stenroth's $(1923 ; 1929)$ advice, rural elementary school pupils could do gymnastics in school corridors, at desks, on seats and tables. Stenroth had compiled ten gymnastics programs to this purpose (Stenroth, 1923; Stenroth, 1929). Creating the method of doing gymnastics at desks proves how important gymnastics was considered: doing it was molded according to the circumstances. In addition to cramped working conditions, lack of equipment hindered exercising at rural schools (Somerkivi, 1985). Works from experts in various sports were used as textbooks (Annuals 1921-1970; e.g. Björkstén, 1920; Björkstén, 1926; Collan, 1908; Collan, 1920; Collan, 1921; Collan, 1922; Collan, 1928; Collan, 1930; Jalkanen, 1922; Koskimies \& Karvonen, 1931; Pulkkinen, 1946; Stenroth, 1926).

Still in the 1910s, women's sport was a relatively new concept that was taken in a quite prejudiced manner (see Koivusalo, 1982). These prejudices melted away by the end of the 1930s when teaching turned into more goal-oriented as well (OMA, TSeA, Dd:1). Pupils were raised into brisk and sportive citizens who followed rules. In addition, one of the motives in the Finnish physical education was to awake nationalism and to emphasize and protect love of one's country (Koivusalo, 1982). Patriotism was manifested through doing exercises that emphasized the Finnish culture and folklore. Therefore, learning folk dances strengthened national traditions (OMA, TSeA, Dd:1; OMA, TSeA, Dd:2).

In the 1930s, an evident characteristic of Finnish culture was the emphasis on sport, especially skiing (Kuikka, 1991a; Vasara, 1997). Skiing started at the teacher training college of Tornio already at the end of the 1920s. One of the problems was that not all students had skis of their own. Principal Loukola applied to the National School Board for 20 pairs of skis. He gave reasons for the demand in the following way: “...because only a few college students have skis, although they would be quite necessary in sport education and sporting performances" (OMA, TSeA, Da:2). Orienteering studies were started at the end of the 1930s (Annuals 1928-1945).

A new sport was introduced at the college in the 1930s: the Finnish version of baseball (OMA, TSeA, Dd:1). At the end of the 1940s, Principal Törmälä applied to the National Board of Education for building a 100-yard track nearby the college building. The nearest sport field was located in the city of Tornio and going there took time. In addition, college students had to go to the field wearing gym clothes because the field did not have facilities where to change clothes (OMA, TSeA, Da:2). Along decades, new sport equipment was purchased, such as stopwatches, ball, gymnastic equipment, and javelins. Sports that were included in physical education did not change much by the 1970s (Annuals 1921-1970). According to the teacher students' interviews, they were turned into multiply skilled persons in sports. Marjatta reminisced: "The goal of the college was to make us multitalented sportswomen. I remember when we had the final exam in sports and I and my roommate woke up at 5 a.m. and went to the sports field of Tornio to learn hurdle. We surely practiced seriously". Physical education at the college of Tornio was similar to the education provided at other Finnish teacher training colleges (e.g. Halila, 1963; Heikkinen, 1990; Heikkinen, 1995; Hyyrö, 2006).

\section{Discussion}

Where have we come in art education since the decades the teacher training college of Tornio operated? What is the position and value of art education in today's schools and teacher education curricula? In Finland, art teachers are obliged to justify and give reasons for art education (Pohjakallio, 2006). The public debate shows that both teachers and students have expressed their concern of the possibility to teach and study arts at school. And this concern is not made-up. 
The proportion of art education in graders 3-6 has decreased from $31 \%$ to $20 \%$ (Kauranne, 1994). According to Erkkilä (2003), the proportion of art education in compulsory studies has been at its lowest since 1994. Likewise, the proportion of obligatory studies of art education (music and fine arts) in class teacher education decreased from approximately 10.4 study weeks (in 1990) to approximately 6.4 study weeks in teacher education departments of Finland - and the tendency has kept up in this millennium as well (Vesioja, 2006).

Today, Finnish teachers and teacher educators have to explain why art education is significant and valuable both for individuals and the society. It is reasonable to ask whether children and youngsters have the opportunity to get quality art education at day care and at school. Are teacher students provided with quality art education in teacher education? What should art education be like (see Siegesmund, 1998)? What have we learned from the one-century-long history of teacher education in Finland?

Art education had its own purposes a century ago and they were reflections from the contemporary societal situation (Efland, 1995). Today, cultural and art education has a special role if the aim is to educate active, co-operative, and responsible citizens. Whether the question was of fine art education (Elliott, 1995; Sederholm, 1998), music education (Elliott, 1995; Pugh \& Pugh, 1998; Swanwick, 1994), physical education (Kunnari, 2011), handicraft education (Hast, 2011), or something else (Duncum, 2001; Gude, 2004), the offering of art education is irreplaceable. In the learning environment provided by art education, skills that may prove valuable not only to art, but also for example, balance development, mental well-being, science, economic life, and overall societal development, will grow and develop.

What is art making depends on contemporary conventions, cultural and material contexts, and regulation systems (MacDonald, 1998). Thus, the border between art and skillful doing is wavering if the starting point is knowledge of rules guiding action, the ability to apply them and create new, and satisfaction that results from doing (cf. Lehtonen, 1994). In modern art, skillful doing could be the courage of indulge in free associating by works of art which necessitates a certain level of knowledge about discourse in the field of modern art. In youngsters' everyday life, skillful doing could be, for example, to use a computer in a versatile manner or to send a text message without looking at the mobile phone (Karpati \& Kovaks, 1997). As youngsters develop their skills and self-regulation while learning these activities, they develop that symbolism and those rules that define the skills they practice.

The role art education has in today's curricula is based on the development of school subjects. English curriculum researcher Ivor Goodson (e.g. 1991, 1995, 2001) does talk about the "evolutionary" model of school subject development. The model consists of four levels of development: (1) the school subject is created and it originates in teachers' action and ideas; (2) teachers try to promote the school subject, its resources, and status within the educational system; (3) if the promotion succeeds, the school subject will be defined by law and increasing attention to it will be paid in science and research; and (4) finally, the school subjects gets an automatically supported and established status. Furthermore, Goodson (2001) has studied what kinds of social processes and historical constructions define and have defined how the written curriculum is formed and realized at the school level (see also Eckhoff, 2008).

Along with changes in the society, art education has to change but not vanish! According to Gude: "art examples and projects in school art curricula should not be reductive representations of theoretical principles, but should reflect the complexity of actual art" (Gude, 2004, p. 12). She continues: "By structuring art projects to introduce students to relevant contemporary art and thus to postmodern principles-strategies for understanding and making art today-students will gain the skills to participate in and shape contemporary cultural conversations" (Gude, 2004, p. 13).

Art teachers' professional skills are of crucial importance, too. A study in the United States (see La Porte, Speirs, \& Young, 2008) showed that art education theory learned in higher education influenced practice in the classrooms of art teachers greatly. Art Teacher and Doctor of Art Sirkka Laitinen said in her address about the reasons why to teach art at school: "In order to develop artistically, a pupil need someone to walk by his or her 
side, someone who can help and give competent advice" (Laitinen, 2006, p. 43). Indeed, as our study showed, art education begins from teacher training and still today, art education as a part of teacher education should also be carefully paid attention to and catered for.

\section{Conclusion}

The description of the last century art education at teacher training colleges of Finland provides interesting information about how important the mastery over art subjects was considered for teachers. The picture drawn in this study is based on primary sources, an abundant archival material that was complemented and vivified through interviews of actual teacher students who studied at the college in the 1930s-1960s. Their memories were very similar which implies that they are correct and truthful. Still, the process where experiences of teacher training turn into memories of teacher training is a multiphase, constantly changing event: experiences are forgotten, remembered, valued, renewed, and changed. Therefore, experiences and memories stratify and interconnect over and over again (see Koselleck, 1992).

Especially in the field of historical research, memories have been taken in a prejudiced and contradictory manner as they are considered subjective and unreliable (Portelli, 1997). It is true that we cannot be certain whether the interviewees' experiences are psychologically true or not (Passerini, 1989; Portelli, 1997; Ukkonen, 2002). On the other hand, personal documents are subjectively true and they have to be treated from that perspective. Although memories can be taken with a grain, experiences are important: the fact what the participant's experience was like in some certain situation. Even in this data, the interviewees told how they "remember that like it was yesterday" or "that kind of experience will never be forgotten" (cited from Ukkonen, 2002); and thus, interview data describe the events as they appear inside the interviewees' minds as it is not possible to reconstruct the past as it really was. Many factors affect an individual's memories: later happening, others' experiences, literal sources, and communally appropriate interpretation of the part (see Peltokorpi, 2011). Eventually, it is important what people think is worth remembering and telling and how they remember, interpret, and produce their history.

Both the archival sources and interviews showed the emphases that were given in art education at the teacher training college of Tornio in 1921-1970. Music education included the entities of decency, Christianity, and patriotism. They were manifested in the forms of lyrics, song selections, and choir activity (e.g. Helasvuo, 1961; Ingman, 1962; Kotilainen, 1924; Törnudd, 1920; Törnudd, 1921; Vainio, 1920). Prospective elementary school teachers were transmitted that knowhow that was needed in a teacher's work. Song they had to learn and the ability to teach playing were considered the means. Choir activity improved their singing but also provided the readiness for acting as a choirmaster. The influence of Herbart-Zillerism was evident in textbooks at the beginning of the 1920s but decreased along with changes in textbooks (Paksuniemi, 2009; Paksuniemi \& Määttä, 2011c).

The teaching of manual skills prepared teacher students for a teacher's work and for women's life, too. They had to be able to sew clothes and as husbandry was the basic idea, they had to know how to patch clothes as well. Here the societal significance of a subject is emphasized as citizens were raised into industrious and careful workers (See also Heikkilä 2008; Tuomaala 2004). This is closely connected with the goal of educating not only decent citizens but also basic skills of societal life along with Herbart-Zillerist ideology (Herbart, 1806; Ziller, 1857, Ziller, 1876). Likewise, according to Cyngaeusian thinking, work and industrious laid the foundation of decent citizenship (Cygnaeus, 1910). Handicraft education strengthened students' will and taught them methodicalness, tidiness, and meticulousness (see Heikkilä, 2008; Tuomaala, 2004).

The purpose of diligent and versatile exercising in PE lessons was to raise brisk citizens. In addition, learning careful gymnastics movements taught how to follow rules in a regimented way. A brisk and obedient citizen was an efficient member of a civic society and therefore physical education was part of citizenship education (see also Tuomaala, 2004). For example, learning folk dances functioned as a part of socializing with 
the Finnish cultural identity.

\section{References:}

Archival sources

OMA: The Provincial Archives of Oulu

TSeA: The Archives of the College of Tornio

Ae: 2 Classroom diaries 1922-1923

Ae: 19 Classroom diaries 1929-1930

Ae: 21 Classroom diaries 1939-1941

Ae: 28 Classroom diaries 1944-1945

Da: 2 Letters 1929-1940

Dd: 1 Curricula 1921-1946

Dd: 2 Curricula 1926-1970

Ca: 2 The proceedings of teachers' meetings 1928-1936

Ca: 3 The proceedings of teachers' meetings 1936-1945

Ca: 4 The proceedings of teachers' meetings 1945-1950

Ca: 5 The proceedings of teachers' meetings 1950-1955

Ca: 6 The proceedings of teachers' meetings 1955-1960

Ca: 7 The proceedings of teachers' meetings 1960-1965

Ca: 8 The proceedings of teachers' meetings 1965-1970

Aldrich, R. (2003). The three duties of the historian education. Journal of the History of Education Society, 32(2),

133-143. <http://dx.doi.org/10.1080/00467600304154>

Björkstén, E. (1920). Women's gymnastics. Part one [In Finnish]. Helsinki: Otava.

Björkstén, E. (1926). Women's gymnastics. Part two [In Finnish]. Helsinki: Otava.

Collan, A. (1908). Singing games [In Finnish]. Helsinki: Raittiuskansan kirjapaino.

Collan, A. (1920). Course echos I [In Finnish]. Helsinki: Raittiuskansan kirjapaino.

Collan, A. (1921). Course echos II [In Finnish]. Helsinki: Raittiuskansan kirjapaino.

Collan, A. (1922). Folk dances. A selection from a Finnish Kisapirtti [In Finnish]. Helsinki:

Kustannusosakeyhtiö Kirjan Kirjapaino.

Collan, A. (1928). Game echos [In Finnish]. Helsinki: Raittiuskansan Kirjapaino.

Collan, A. (1930). A small sport guide for women and girls [In Finnish]. Helsinki: Otava.

Duncum, P. (2001). Visual culture: Developments, definitions, and directions for art education. Studies in Art Education, 42(2), 101-112. <http://dx.doi.org/10.2307/1321027>

Eckhoff, A. (2008). The importance of art viewing experiences in early childhood visual arts: The exploration of a master art teacher's strategies for meaningful early arts experiences. Early Childhood Education Journal, 35, 463-472. <http://dx.doi.org/10.1007/s10643-007-0216-1>

Efland, A. (1995). Change in the conceptions of art teaching. In W. R. Neperud (Ed.), Context, content and community in art education (pp. 25-40). New York, NY: Teachers College Press.

Elliott, D. J. (1995). Music matters: A new philosophy of music education. New York, NY: Oxford University Press.

Erkkilä, T. (2003). Art education in the basic education at school. The development and present situation of the comprehensive school time in the light of a survey [In Finnish]. University of Oulu, Oulu.

Goodson, I. F. (1991). Sponsoring the teacher's voice: teachers' lives and teacher development. Cambridge Journal of Education, 21(1), 35-45. <http://dx.doi.org/10.1080/0305764910210104>

Goodson, I. F. (1995). The making of curriculum: Collected essays. London and Philadelphia: Falmer Press.

Goodson, I. F. (2001). Social histories of educational change. Journal of Educational Change, 2(1), 45-63. <http://dx.doi.org/10.1023/A:1011508128957>

Cygnaeus, U. (1910). Uno Cygnaeus's writings about the establishment and organization of Finnish elementary school [In Finnish]. Helsinki: Raittiuskansan kirjapaino.

Granfelt, R. (1998). Narratives about women's homelessness [In Finnish]. Helsinki: Finnish Literature Association. 
Paksuniemi, M., Uusiautti, S., \& Määttä, K.

Grossman, P, \& Thompson, C. (2008). Learning from curriculum materials: Scaffolds for new teachers?

Teaching and Teacher Education, 24(8), 2014-2026. <http://dx.doi.org/10.1016/j.tate.2008.05.002>

Gude, O. (2004). Postmodern principles: In search of a 21st century art education. Art Education, 57(1), 6-14.

Halila, A. (1949). The history of the Finnish school system part I [In Finnish]. Turku: Uuden Auran Osakeyhtiön Kirjapaino.

Halila, A. (1963). The history of the teacher training college of Jyväskylä [In Finnish]. Porvoo \& Helsinki: Otava.

Hast, M. (2011). The construction of the technology of cCrafts: An analysis and interpretation process about technology as a part of general crafts education [In Finnish]. Rovaniemi: University of Lapland.

Helasvuo, V. (1961). The history of music [In Finnish]. Helsinki: Otava.

Herbart, J. F. (1806). General pedagogy [In Finnish]. Leipzig: B. Reklam.

Heikkilä, A. (2008). Clothes in the life a child. Clothing of a schoolchild in a countryside village in Northern Finland during the years 1909-1939 [In Finnish]. Rovaniemi: University of Lapland.

Heikkinen, R. (1990). Schooling and education in the city of the woods. The 90th anniversary of the teacher education department of Kajaani [In Finnish]. Oulu: University of Oulu.

Heikkinen, R. (1995). Education and schooling in Kainuu. The development of the school system of Kainuu by the September 1945 [In Finnish]. Oulu: University of Oulu.

Hollo, J. A. (1919) Imagination and how to foster it. A psychological and educational study, part II [In Finnish]. Porvoo: WSOY.

Hymander, I., \& Ahlfors, A. (1906). Basics of piano playing I [In Finnish]. Helsinki: Oy R. E. Westerlund Ab.

Hyry, E.- K., \& Hyvönen, L. (2003). Music in a teacher's life [In Finnish]. In H. L. T. Heikkinen \& L. Syrjälä (Eds.), Many narratives live in me. Writings about teacherhood [In Finnish] (pp. 64-84). Helsinki: Kansanvalistusseura.

Hyyrö, T. (2006). The development of elementary school teacher training in Finland 1866-1939 [In Finnish]. Tampere: Tampere University Press.

Iisalo, T. (1989). The phases of education from the medieval cathedral school to modern schools [In Finnish]. Keuruu: Otava.

Ingman, O. (1962). School singing book [In Finnish]. Helsinki: WSOY.

Isosaari, J. (1961). The education of the science of education and pedagogy at the teacher training college of Jyväskylä in 1865-1901 [In Finnish]. Jyväskylä: University of Jyväskylä.

Jalkanen, H. (1922). Command practices for four-week gym master courses [In Finnish]. Helsinki: Otava.

Karpati, A., \& Kovaks, Z. (1997). Teenage art: Creating the self. Journal of Art and Design Education, 16(3), 295-302. <http://dx.doi.org/10.1111/1468-5949.00089>

Kauranne, J. (1971). The efforts of integrating elementary school education in 1912-1939 [In Finnish]. Helsinki: University of Helsinki.

Koivusalo, I. (1982). Gymnastics as a subject in the schools of our country 1843-1917 [In Finnish]. Helsinki: Liikuntatieteellinen seura.

Koselleck, E. (1992). The influence of both World Wars in the social conscience [In Finnish]. In H. Wette (Ed.), A little man's war. A soldier's story from the grassroot level [In Finnish] (pp. 324-333). München: Grim.

Koskimies, A., \& Karvonen, I. (1931). Command exercises [In Finnish]. Porvoo: WSOY.

Kotilainen, O. (1924). School songs [In Finnish]. Helsinki: WSOY.

Kunnari, A. (2011). The experience-based capital of physical exercise and the holistic conception of human being in PE teachers' work [In Finnish]. Rovaniemi: Lapland University Press.

Lahtinen, J. N., \& Lampén, S. (1927). Elementary school singing and singing game book [In Finnish]. Helsinki: Valistus.

Lahtinen, J. N., \& Lampén, S. (1931). Elementary school singing and singing game book [In Finnish] (2nd ed.). Helsinki: Valistus.

La Porte, A. M., Speirs, P., \& Young, B. (2008). Art curriculum influences: A national survey. Studies in Art Education, 49(4), 358-370.

Laitinen, S. (2006). Why to teach fine arts at school and what should a teacher know about it? [In Finnish]. In In 
R. Jakku-Sihvonen (Ed.), Meanings of art education [In Finnish] (pp. 33-45). Helsinki: Theatre Academy Helsinki.

MacDonald, S. W. (1998). Post-it culture: Postmodernism and art design education. Journal of Art and Design Education, 17(3), 227-235. <http://dx.doi.org/10.1111/1468-5949.00131>

McGulloch, G., \& Watts, R. (2003). Introduction: Theory, methodology, and the history of education. Journal of the History of Education Society, 32(2), 129-132. <http://dx.doi.org/10.1080/00467600304153>

Melin, V. (1980). Primary education in Finnish countryside before the Act on Compulsory Education in1866-1921. The joining of primary education in the municipal comprehensive school 1906-1921 [In Finnish]. Tampere: University of Tampere.

Merseth, K. (1991). The early history of case-based instruction: Insights for teacher education today. Journal of Teacher Education, 42(4), 243-249. <http://dx.doi.org/10.1177/002248719104200402>

Nurmi, V. (1964). The birth and development of our actual teacher training during the last century [In Finnish]. Jyväskylä: University of Jyväskylä.

Nurmi, V. (1989). From elementary school to comprehensive school [In Finnish]. Juva: WSOY.

Nurmi, V. (1995). Suomen kansakouluopettajaseminaarien historia [The history of Finnish elementary school teacher training colleges]. Helsinki: OAJ.

Paavola, M. (1949). The basics of piano playing [In Finnish] (3rd ed.). Porvoo: WSOY.

Paksuniemi, M. (2009). The teacher image in the lower primary school teachers college of Tornio in 1921-1945 in the light of selection of students, textbooks, and activities of leisure time [In Finnish]. Unpublished Doctoral dissertation, University of Lapland, Rovaniemi.

Paksuniemi, M., \& Määttä, K. (2011a). The most decent girls make the best responsible teacher - teacher selection for teacher education in Northern Finland in 1921-1945. Prime Research on Education, 1(1), 10-17.

Paksuniemi, M., \& Määttä, K. (2011b). How were the students turned into decent teachers by free-time activities at the teacher training college of Tornio in 1921-1945. Elixir Psychology, 39, 4782-4786.

Paksuniemi, M., \& Määttä, K. (2011c). At the roots of pedagogy of Finnish teacher training -practicum as a core of teacher training in teacher college of Tornio in the 1920s. International Journal of Educational Administration and Policy Studies, 3(8), 121-128.

Passerini, L. (1989). Women's personal narratives: Myths, experiences, and emotions. In Personal Narrative Group (Eds.), Interpreting women's lives (pp. 189-197). Bloomington: Indiana University Press.

Parviainen, L. (1936). School singing book [In Finnish] (2nd ed.). Porvoo: WSOY.

Parviainen, L. (1946). School singing book [In Finnish] (7th ed.). Helsinki: Otava.

Peltokorpi, K. M. (2011). You have to live for the moment because any moment may be your last one - How did lottas survie at war in 1939-1945? [In Finnish]. Rovaniemi: University of Lapland.

Pohjakallio, P. (2006). Debade about the position of art at school - the continuing need for justifications for art education [In Finnish]. In R. Jakku-Sihvonen (Ed.), Meanings of art education [In Finnish] (pp. 10-32). Helsinki: Theatre Academy Helsinki.

Portelli, A. (1997). The battle of Valle Giulia. Oral history and the art of dialogue. Madison, WI: The University of Wisconsin Press.

Pugh, A., \& Pugh, L. (1998). Music in the early years. London: Routledge.

Pulkkinen, A. (1946). Finnish folk dances. Helsinki: WSOY.

Rinne, R. (1989). Where do teachers come from? The societal background and social capital of Finnish teachers from the middle of the 1800s to the end of the 1980s [In Finnish]. Turku: University of Turku.

Scott, J. (1991). The evidence of Experience, Critical Inquiry/17. Chicago, IL: University of Chicago.

Sederholm, H. (1998). Starting to play with arts education. Study of ways to approach experiential and social modes of contemporary art. Jyväskylä: University of Jyväskylä.

Siegesmund, R. (1998) Why do we teach art today? Conceptions of art education and their justification. Studies in Art Education, 39(3), 197-214. <http://dx.doi.org/10.2307/1320364>

Siukonen, V. (1954). Music education: music schools, seminars for self-learners [In Finnish]. Helsinki: Otava. Somerkivi, U. (1985). Elementary school curricula as the mirrors of cultural transmittance [In Finnish]. In 
Paksuniemi, M., Uusiautti, S., \& Määttä, K.

School and culture, School and past XXIII [In Finnish] (pp. 7-62). Porvoo: WSOY.

Stenroth, F. (1923). Elementary school gymnastics. Program of the upper rural elementary school [In Finnish]. Helsinki: Otava.

Stenroth, F. (1926). Child gymnastics. Manual of gymnastics for elementary education. Third education, Part I [In Finnish]. Helsinki: Otava.

Stenroth, F. (1929). Elementary school gymnastics. Program of the upper rural elementary school [In Finnish]. Helsinki: Otava.

Swanwick, K. (1994). The "reform" of teacher education in England. Research Studies in Music Education, 2, 2-7. <http://dx.doi.org/10.1177/1321103X9400200102>

Teerisuo, I. (1950). How to care for your clothes properly [In Finnish]. Helsinki: Teacher training college of Helsinki.

Teerisuo, I. (1964). A skillful girl sews and dresses herself well [In Finnish]. Helsinki: WSOY.

Tuomaala, S. (2004). From working hands into clean and writing ones. The confrontation of the Finnish comprehensive school and rural people 1921-1939 [In Finnish]. Helsinki: Finnish Literature Association.

Turunen, L. (1946). Sewing I [In Finnish]. Helsinki: Otava.

Turunen, L. (1966). Sewing I [In Finnish]. Helsinki: Otava.

Törnudd, A. (1920). School singing book [In Finnish] (3rd ed.). Porvoo: WSOY.

Törnudd, A. (1923). The history of music overall [In Finnish] (2nd ed.). Helsinki: Otava.

Törnudd, L. (1929). The new textbook of handicrafts, Part I. Exercises for the actual elementary grades [In Finnish] (5th ed.). Jyväskylä: Gummerrus.

Ukkonen, T. (2002). Interpreting the past through narratives. Memories as the process of producing one's own history and stories about experiences [In Finnish]. Helsinki: Finnish Literature Association.

Vainio, J. N. (1920). The singing book of enlightenment [In Finnish] (11th ed.). Helsinki: Osakeyhtiö Valistus. Valve, T., \& Tappura, K. (1937). Handicraft for elementary school [In Finnish] (3rd ed.). Porvoo: WSOY. Vesioja, T. (2006). A classroom teacher as a music educator [In Finnish]. Joensuu: University of Joensuu. Wohlfahrt, R., \& Merikanto, O. (1904). The new basic piano class [In Finnish]. Helsinki: Oy Fazer.

Woods, P. (1985). Conversations with teachers. Some aspects of life-history method. British Educational Research Journal, 11(1), 13-26. http://dx.doi.org/10.1080/0141192850110102

Ziller, T. (1857). Controlling a child [In Finnish]. Leipzig: Drud un Berlag von B.G. Teubner.

Ziller, T. (1876). General pedagogy [In Finnish]. Leipzig: Geinrich Matthes. 